\title{
Generalization along the dimension of length of line without explicit discrimination training: A replication '
}

\author{
RICHARD W. MALOTT, MARILYN KAY MALOTT, AND JOHN G. SVINICKI \\ WESTERN MICHIGAN UNIVERSITY
}

The hypothesis that the peaked generalization gradients obtained without explicit discrimination training can be explained by implicit discrimination training between the response key and the wall of the test chamber was investigated. Pigeons were reinforced for pecking a key transilluminated with a white $1.3 \mathrm{~cm}$ line on a black background; the wall of the test chamber was also illuminated. A peaked line length generalization gradient was obtained even though the implicit discrimination training probably occurred between the black background and the wall. This result seems to contradict the experimental hypothesis.

Malott \& Malott (1967) presented an interpretation of the fact that some investigators (Butter \& Guttman, 1957; Heineman \& Rudolph, 1963; Newman \& Barron, 1965) found flat generalization gradients without explicit discrimination training, while other investigators (Guttman \& Kalish, 1956; Butter, 1963) obtained peaked gradients. Their analysis indicates that a training situation in which the chamber is illuminated and there is no explicit discrimination training with a stimulus located in the center of the response key would result in a flat generalization gradient. The assumption is that the relatively dark key would be easily discriminable from the illuminated chamber wall and it would not be necessary to attend to the stimulus on the key.

They did not find this prediction confirmed in their study. The data were confounded due to the houselight being off for the first two days of the experiment. This may have provided enough implicit discrimination training with the stimulus in the center of the key to produce the peaked generalization gradient.

The present study was intended to retest the prediction without the organism ever being in the chamber with the houselight off and the stimulus on.

Subjects

The Ss were three experimentally naive White Carneaux barren hen pigeons. They were maintained at $70 \%$ of their free-feeding body weights with Purina Pigeon Grains, which also served as the reinforcer. Grit and water were continuously available in the home cage.

\section{Apparatus}

The chamber used was a Lehigh Valley Electronics plgeon test chamber (No. 1519c) with a houselight. The key was a transparent disc 1-1/4 in. in diameter behind which stimuli were projected with an Inline Readout projector. Masking noise was presented through a speaker in the test chamber. Solid state digital switching circuitry was used to program stimulus presentations and reinforcements during training. The stimuli were manually controlled during generalization tests. Responses and reinforcements were recorded with electromechanical counters and a cumulative recorder.

Procedure

Using standard operant conditioning procedures and food reinforcements, the Ss were shaped to peck a key with the houselight on. The stimulus on the key was a horizontal line $1.3 \mathrm{~cm}$ long with a vertical 0.7 cm line centered on each end. There was no negative stimulus correlated with nonreinforcement. The houselight remained on at all times. Training consisted of a gradual increase of the response requirements
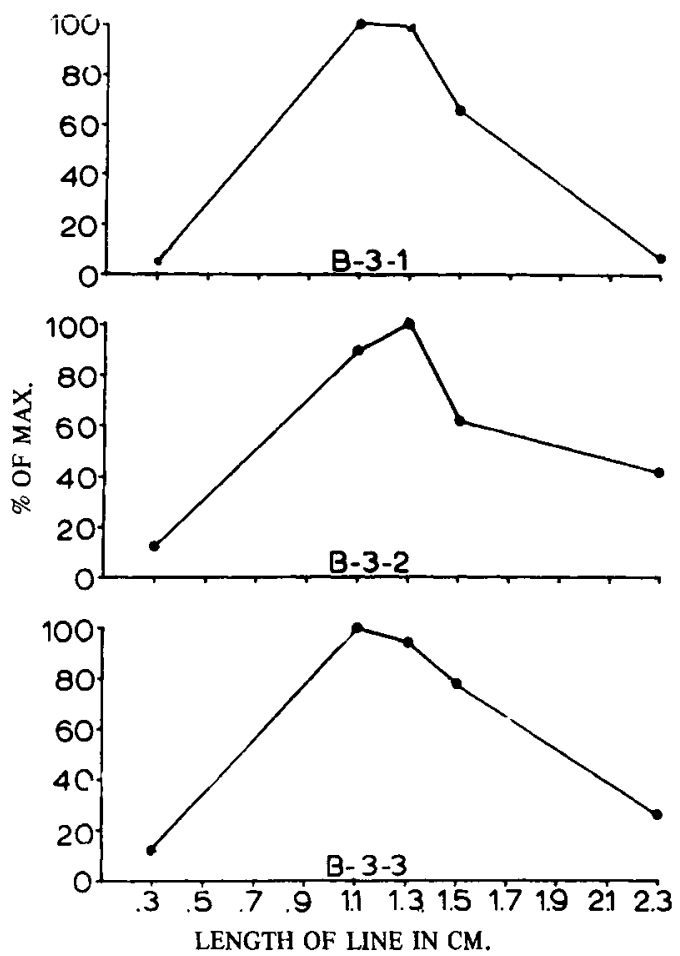

Fig. 1. Percent of maximum amount of responses (peak) as a function of line length. 
to a random-interval $64 \mathrm{sec}$ schedule of reinforcement. The probability of the first response in each 4 sec period was 1/16 (cf., Farmer, 1963). After 15 sessions on this schedule a generalization test was given in extinction.

\section{Resulis and Discussion}

As can be seen in Fig. 1, each gradient does have a pronounced maximum. A peak in the generalization gradient can be obtained even when the houselight is on during training and testing. This may indicate that implicit discrimination training between the chamber wall and the line stimulus in the center of the key is not necessary for the line to exert stimulus control. Another interpretation may be that the parameters of the visual complex were such that the implicit discrimination did occur in spite of the central location of the stimulus. This last interpretation would limit the generality of the notion that the stimulus should be on the border between the response key and the chamber wall in order for implicit discrimination to occur (cf., Meyer et al, 1965).

References

BUTTER, C. M., \& GUTTMAN, N. Stimulus generalization and discrim- ination along the dimension of angular orientation. Amer. Psychol., 1957, 12, 449 (abstract).

BUTTER, C. M. Stimulus generalization along one and two dimensions in pigeons. J. exp. Psychol., 1963, 65, 339-346.

FARMER, J. Properties of behavior under random interval reinforcement schedules. J. exp. Anal. Behav., 1963, 6, 607-616.

GUTTMAN, N., \& KALISH, H. I. Discriminability and stimulus generalization. J. exp. Psychol, 1956, 51, 79-88.

HEINEMAN, E. G., \& RUDOLPH, R. L. The effects of discriminative training on the gradients of stimulus-generalization. Amer. J. Psychol, $1963,76,653-658$.

MALOTT, R. W., \& MALOTT, MARILYN K. An analysis of the MuellerLyer illusion in terms of stimulus generalization. Submitted for publication, J. exp. Anal Behav., 1967.

MEYER, D. R., TREICHLER, F. R., \& MEYER, P. M. Training techniques and stimulus variables. In Schier, Harlow, \& Stollnitz (Eds.), Behavior of nonhuman primates. Vol. 1. New York: Academic Press, 1965.

NEWMAN, F. I., \& BARRON, M. R. Stimulus generalization along the dimension of angularity: a comparison of training procedures. $J$. comp. physiol Psychol, 1965, 60, 59-63.

Note

1. This research was supported by Public Health Service Grant MH 13178-01. 